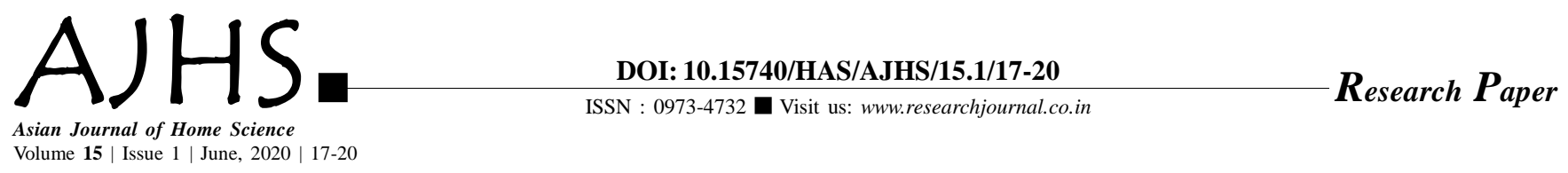

\title{
Socio-economic status of farm women in Coastal Odisha
}

\author{
C. Devadarshini and D. Jena
}

Received: 08.11.2019; Revised: 04.03.2020; Accepted: 18.04.2020

See end of the paper for authors' affiliations

\section{Devadarshini}

Department of Food Science and Nutrition, College of

Community Science, Odisha

University of Agriculture and

Technology, Bhubaneswar

(Odisha) India

Email : chitramickey@gmail.com
Received: 08.11.2019; Revised: 04.03.2020; Accepted: 18.04 .2020 ABSTRACT : In Indian society, women have a multi dimensional role. The largest number of
women in India is engaged in farming operations either as cultivators or as supervisors or as agricultural labourers. A study was conducted to assess the socio-economic status of women in agriculture in coastal districts of Odisha during the year 2013-14. The findings suggested that majority of the farmers $(63.14 \%$ ) were under BPL ( Below Poverty Line). When male wage rate was compared to female wage rate for agricultural activities, females represented a lower value Rs. 186.66/day compared to male workers (Rs. 235.57 \pm 15.31 ), and it was statistically significant $\left(\mathrm{Z}=11.71^{* *}, \mathrm{p}<0.01\right)$ for male workers. The average total monthly income of the household was Rs. 3459.74. Women were earning less for both in agricultural (Rs. 292.33) and non-agricultural activity (Rs. 244.68) compared to male farmers (Rs. 859.96 for agriculture and Rs. 704.72 for non agricultural activity). The study clearly showed that there was gender inequality in case income of the women between the male and the female farmers.

KEY WORDS: Socio-economic status, Farm women

— HOW TO CITE THIS PAPER : Devadarshini, C. and Jena, D. (2020). Socio-economic status of farm women in Coastal Odisha. Asian J. Home Sci., 15 (1) : 17-20, DOI: 10.15740/HAS/AJHS/15.1/17-20. Copyright@ 2020: Hind Agri-Horticultural Society. 